\title{
Tropical reef-fish disease outbreaks and mass mortalities in Florida, USA: what is the role of dietary biological toxins?
}

\author{
Jan H. Landsberg \\ Florida Marine Research Institute, Florida Department of Environmental Protection, 100 Eighth Avenue Southeast, \\ St. Petersburg, Florida 33701-5095, USA
}

\begin{abstract}
From November 1993 to February 1994, heavy mortalities of tropical reef fish were reported in the Palm Beach area on Florida's southeast coast and the Islamorada area in the upper Florida Keys. Severely affected fish were typically adult herbivores or omnivores such as the angelfishes Pomacanthus paru and $P$. arcuatus, the rock beauty Holacanthus tricolor, the cherubfish Centropyge argi, the princess parrotfish Scarus taeniopterus, the blue chromis Chromis cyaneus, the balloonfish Diodon holocanthus, the whitespotted filefish Cantherhines macroceros, the doctorfish Acanthurus chirurgus, and less severely affected, the reef butterflyfish Chaetodon sedentarius and the foureye butterflyfish C. capistratus. Diseased fish typically had lesions on the anterior part of the head, ulcerated body sores, fin and tail rot, and a heavy mucus coating on the body surface. Protistan parasites such as Brooklynella hostilis, Uronema marinum, and amoebae were common. Turbellarians and bacterial infestations were also detected. There is, however, no evidence that these potential pathogens are the principal cause of the disease syndrome and resultant fish mortality they may be secondary invaders of fish whose health has already been compromised. The possibility is considered that biological toxins from macroalgae such as Caulerpa spp., or from benthic dinoflagellates such as Gambierdiscus toxicus may act as principal stressors that influence reef-fish health. A possible link between some of the mass mortalities in Florida and those in the Caribbean in the past $15 \mathrm{yr}$ is postulated. The causative chain of events leading to these mortalities should be studied in a larger ecosystem framework, but the immediate need for a program monitoring reeffish diseases is also discussed.
\end{abstract}

\section{INTRODUCTION}

In June and July 1980, prior to Hurricane Allen, a mass mortality of tropical reef fish occurred from the coastal region of southeastern Florida through the Florida Keys to the Dry Tortugas (Burns 1981). In August and September 1980, after Hurricane Allen, further widespread aquatic mortalities were recorded in the Caribbean (Atwood 1981). Since that time, a wide range of aquatic diseases and mass mortalities involving stony corals, gorgonians, sponges, seagrasses, molluscs, sea urchins, fish, turtles, and birds have been recorded in the region (Williams \& BunkleyWilliams 1987, 1990a). Although a number of causative agents ranging from environmental factors to specific pathogens have been suggested (Williams \& Bunkley-
Williams 1987), none have been conclusively demonstrated to be responsible for these various mortalities In addition, widespread coral bleaching and mortalities have been reported in this area (Williams \& Bunkley-Williams 1987, 1990b, Jaap 1988).

From November 1993 to February 1994, heavy mortalities (estimated to be several thousands) of tropical reef fish were reported in the Palm Beach area on the lower southeast coast of Florida and in the Islamorada area in the upper Florida Keys. The present communication provides preliminary details of the disease syndrome associated with the most recent mortalities, contributes new information about the 1980 Florida reef-fish mortalities, and proposes one possible link between some of the mass mortalities that have occurred in Florida and in the Caribbean in the past $15 \mathrm{yr}$. 


\section{MATERIALS AND METHODS}

Four live, diseased adult angelfish ( 3 grey Pomacanthus arcuatus and 1 French $P$. paru) and 1 rock beauty Holacanthus tricolor were obtained during an ongoing disease outbreak near Boynton Beach, Florida (Briney Breezes Reef, $26^{\circ} 44^{\prime} \mathrm{N}, 80^{\circ} 00^{\prime} \mathrm{W}$ ), on 18 December 1993. The fish were caught by hand net on the reef at a depth of 25 to $30 \mathrm{~m}$; their swimbladders were deflated by needle. Fish were held in a livebox until. sampling was complete. A few representative samples of macroalgae, water, and sediments were collected from the same area and depth of the reef. One of the grey angelfish ( $35 \mathrm{~cm}$ TL) died on site, and skin, fin. and gill scrapes from it were examined onshore. The fish was then frozen. The remaining fish were transported live to the Florida Marine Research Institute (FMRI), St. Petersburg. Florida. One of the grey angelfish $(33 \mathrm{~cm}$ TL) died en route and was frozen upon arrival at the Institute. The remaining 3 fish were held in the lab in separate, aerated aquaria filled with artificial seawater (30 ppt Instant Ocean ${ }^{\oplus}$. Aquarium Systems, Inc.). Within $2 \mathrm{~d}$ after capture, the 2 remaining angelfish [French $(30 \mathrm{~cm} \mathrm{TL})$ and grey $(39 \mathrm{~cm} \mathrm{TL})$ ] began to show signs of respiratory distress, had increased opercular movement, and were disoriented. These fish were necropsied when they became moribund. The rock beauty was kept in the aquarium for further observation.

Skin, fin, and gill scrapes; portions of tissue from the posterior kidney, liver, stomach, ceca, anterior and posterior intestine, and gall bladder; and intestinal fluid and bile were examined for parasites by light microscopy. Stomach contents were evaluated. Parallel evaluations of tissues and fluids were also made from stained smears or histological preparations. Smears were air-dried, methanol-fixed, and stained for 20 min with Giemsa: $0.1 \mathrm{M}$ phosphate buffer $(1: 1, \mathrm{pH} 7.4)$. Slides that would be evaluated later were rinsed with $0.1 \mathrm{M}$ phosphate buffer and tap water and were then air-dried.

Histological slides were made from fish tissues that were fixed in $5 \%$ paraformaldehyde in $0.1 \mathrm{M}$ phosphate buffer, dehydrated in a graded ethanol series, and embedded in JB-4 glycol methacrylate resin. Sections were cut to $3.5 \mu \mathrm{m}$ on an LKB 2218 Historange microtome and were stained in Weigert's hematoxylin and eosin, in periodic acid Schiff's-hematoxylinmetanil yellow (Quintero-Hunter et al. 1991), or in thionin stain adapted to glycol methacrylate (Nagle \& Quintero-Hunter unpubl.).

Parasites, either in situ on whole gills or removed from fresh gills, were chemically fixed for scanning electron microscopy (SEM) (Landsberg \& Blakesley 1995). The 2 necropsied angelfish were sent frozen to Dr D. Baden of the Rosenstiel School of Marine and
Atmospheric Science at the University of Miami for ciguatera toxicity testing.

Live, diseased fish were also shipped from Islamorada to the FMRI lab on 13 December 1993 iafter being held in aquarium facilities there for several days). Affected fish were a princess parrotfish Scarus taeniopterus $(21.3 \mathrm{~cm}$ TL), 2 reef butterflyfish Chaetodon sedentarius ( 14.4 and $10.9 \mathrm{~cm} \mathrm{TL}$ ), a foureye butterflyfish $C$. capistratus $(9.5 \mathrm{~cm} \mathrm{TL})$, a blue chromis Chromis cyaneus $(10.6 \mathrm{~cm} \mathrm{TL})$, and a rock beauty (9.0 cm TL). Two balloonfish Diodon holocanthus (22.1 and $21.0 \mathrm{~cm} \mathrm{TL}$ ) that died en route were also examined upon arrival. Fish were held for observation in aquaria. Light microscopy was used to examine fresh squash preparations of skin, fin, and gill scrapes for parasites. Bäcteriologicâi samples were takeñ from a reef butter. flyfish exhibiting lesions on the tail. Swabs from the tail and kidney were plated out on tryptone soy agar media and incubated at $25^{\circ} \mathrm{C}$ (J. Pallias pers. comm.)

The public in the Islamorada and Palm Beach areas informed us of fish kill details and, particularly, of mortalities of French and grey angelfish, rock beauties, blue chromis, parrotfish, and tripletail Lobotes surinamensis. In addition, other diseased fish species were documented from diver observations, photographs, and video footage of the reef in the Palm Beach area (B. Parks pers, comm.).

Historical information was available from the FMRI reports, unpublished information. (B. Roberts pers. comm.), and histological archives concerning the 1980 Florida reef-fish mortalities. These tissues were originally isolated from diseased blue Holacanthus bermudensis and queen $H$. ciliaris angelfish (Burns 1981) and were stored in paraffin blocks. These tissues were reembedded in JB-4 glycol methacrylate (P. Nagle pers. comm.), sectioned, and stained as above.

\section{RESULTS}

The most recent mass reef-fish mortalities began in November 1993 and continued until mid-February 1994. Species in which heavy mortalities occurred are compared in Table 1 with those reported in the 1980 Florida and Caribbean fish kills (Burns \& Roberts unpubl., Atwood 1981). The majority of affected reef fish were adult; most of the species were herbivorous browsers or grazers, omnivores, or piscivores or were 'cleaner fish', which as juveniles feed by picking parasites from other fish. Fish species in which light mortalities were reported are also predominantly mixed feeders, i.e. herbivores, omnivores, or piscivores that feed on herbivorous fish (Table 2). Reef-fish species that seemed to be unaffected in the 1980 or 1993-94 fish kills are not typically herbivores and are usually either 
Table 1. Reef fish severely affected during recent disease and mortality events (1980 to 1994). Families arranged in descending order, from greatest to least affected (Atwood 1981, Burns \& Roberts unpubl., present study). $\mathrm{H}=$ herbivore, $\mathrm{O}=$ omnivore, $\mathrm{P}=$ piscivore, $\mathrm{PL}=$ planktivore, $\mathrm{PS}=$ cleaner fish (crustacean parasites), $\mathrm{C}=$ carnivore

\begin{tabular}{|c|c|c|c|c|}
\hline Family & $\begin{array}{l}\text { Caribbean } \\
1980\end{array}$ & $\begin{array}{l}\text { Florida } \\
1980\end{array}$ & $\begin{array}{l}\text { Florida } \\
1993-94\end{array}$ & Diet \\
\hline \multicolumn{5}{|c|}{ Pomacanthidae } \\
\hline & \multirow{2}{*}{\multicolumn{2}{|c|}{ Pomacanthus spp. }} & Pomacanthus paru & $\mathrm{H} / \mathrm{O}$ \\
\hline & & & Pomacanthus arcuatus & $\mathrm{H} / \mathrm{O}$ \\
\hline & \multirow[t]{2}{*}{ Holacanthus spp. } & Holacanthus bermudiensis & & $\mathrm{H} / \mathrm{O}$ \\
\hline & & Holacanthus ciliaris & & $\mathrm{H} / \mathrm{O}$ \\
\hline & \multirow[t]{2}{*}{ Holacanthus tricolor } & Holacanthus tricolor & Holacanthus tricolor & $\mathrm{H} / \mathrm{O}$ \\
\hline & & & Centropyge argi & $\mathrm{H} / \mathrm{O}$ \\
\hline \multicolumn{5}{|c|}{ Pomacentridae } \\
\hline & & & Chromis cyaneus & $\mathrm{H} / \mathrm{PL}$ \\
\hline & \multicolumn{2}{|l|}{ Abudeduf saxatilis } & & $O$ \\
\hline \multicolumn{5}{|c|}{ Scaridae } \\
\hline & \multirow{2}{*}{\multicolumn{2}{|c|}{ Scarus spp. }} & & $\mathrm{H}$ \\
\hline & & & Scarus taeniopterus & $\mathrm{H}$ \\
\hline \multicolumn{5}{|c|}{ Ephippidae } \\
\hline & \multicolumn{2}{|l|}{ Chaetodipterus faber } & & $\mathrm{H} / \mathrm{O}$ \\
\hline \multicolumn{5}{|c|}{ Acanthurudiae } \\
\hline & Acanthurus chirurgus & Acanthurus spp. & Acanthurus chirurgus & $\mathrm{H}$ \\
\hline \multicolumn{5}{|c|}{ Haemulidae } \\
\hline & \multirow[t]{2}{*}{ Anisotremus surinamensis } & & & $\mathrm{C} / \mathrm{O}$ \\
\hline & & Haemulon spp. & & $\mathrm{C} / \mathrm{O}$ \\
\hline \multicolumn{5}{|c|}{ Lutjanidae } \\
\hline & Ocyurus chrysurus & Ocyurus chrysurus & & 0 \\
\hline & Lutjanus spp. & & & $\mathrm{C} / \mathrm{P}$ \\
\hline & Lutjanus analis & Lutjanus analis & & $\mathrm{C} / \mathrm{P}$ \\
\hline & Lutjanus apodus & & & $\mathrm{P} / \mathrm{C}$ \\
\hline \multicolumn{5}{|c|}{ Balistidae } \\
\hline & & Balistes spp. & & $\mathrm{C}$ \\
\hline & \multirow{2}{*}{ Balistes vetulus } & & & $\mathrm{C}$ \\
\hline & & & Cantherhines macrocerus & $\mathrm{H} / \mathrm{O}$ \\
\hline \multicolumn{5}{|c|}{ Diodontidae } \\
\hline & & ?Chilomycterus sp. & & $\mathrm{O} / \mathrm{C}$ \\
\hline & & & Diodon holocanthus & $\mathrm{O} / \mathrm{C}$ \\
\hline & Diodon hystrix & & & $\mathrm{O} / \mathrm{C}$ \\
\hline \multicolumn{5}{|c|}{ Serranidae } \\
\hline & Epinephelus spp. & Epinephelus sp. & & $\mathrm{P} / \mathrm{C}$ \\
\hline & & Epinephelus itajara & & $\mathrm{P} / \mathrm{C}$ \\
\hline & Mycteroperca spp. & & & $\mathrm{P}$ \\
\hline \multicolumn{5}{|c|}{ Labridae } \\
\hline & Lachnolaimus maximus & Lachnolaimus maximus & & $\mathrm{C}$ \\
\hline & & & ?Bodianus rufus & $\mathrm{PS} / \mathrm{C}$ \\
\hline & & & ?Bodianus pulchellus & PS \\
\hline
\end{tabular}

planktivores or feed on benthic organisms such as polychaetes, molluscs, echinoderms, crustaceans, coral polyps, or other fish (Table 3 ). Conch and frigate birds were affected in the 1980 Florida kill and a barracuda was also reported with hemorrhaging and ulceration around the mouth (B. Roberts unpubl.).
Behavioral signs of disease in fish in 1993-94 seen on video footage or by divers (B. Parks pers. comm.) included 'nervous behavior', increased twitching of fins, and increased prevalence at cleaning stations. The most common species of cleaner fish associated with diseased fish was the spotfin hogfish Bodianus 
Table 2. Reef fish lightly affected during recent disease and mortality events (1980 to 1994). Families arranged in descending order, from greatest to least affected (Atwood 1981, Burns \& Roberts unpubl., present study). $\mathrm{H}=$ herbivore, $\mathrm{O}=$ omnivore, $\mathrm{P}=$ piscivore, $\mathrm{C}=$ carnivore

\begin{tabular}{|c|c|c|c|c|}
\hline Family & $\begin{array}{l}\text { Caribbean } \\
1980\end{array}$ & $\begin{array}{l}\text { Florida } \\
1980\end{array}$ & $\begin{array}{l}\text { Florida } \\
1993-94\end{array}$ & Diet \\
\hline Kyphosidae & $\begin{array}{l}\text { Kyphosus } \\
\text { sectatrix }\end{array}$ & & & $\mathrm{H}$ \\
\hline Lobotidae & & & $\begin{array}{l}\text { Lobotes } \\
\text { surinamensis }\end{array}$ & $\mathrm{H} / \mathrm{O}$ \\
\hline \multirow[t]{2}{*}{ Chaetodontidae } & & & $\begin{array}{l}\text { Chaetodon } \\
\text { sedentarius }\end{array}$ & $\mathrm{O}$ \\
\hline & & & $\begin{array}{l}\text { Chaetodon } \\
\text { capistratus }\end{array}$ & $\mathrm{O}$ \\
\hline Albulidae & Albula vulpes & & & $\mathrm{O} / \mathrm{C}$ \\
\hline Sparidae & Calamus spp. & & & $\mathrm{O}$ \\
\hline \multirow[t]{2}{*}{ Mullidae } & & \multicolumn{2}{|l|}{ Mulloidichthys sp. } & $\mathrm{O}$ \\
\hline & $\begin{array}{l}\text { Pseudupeneus } \\
\text { maculatus }\end{array}$ & & & $\mathrm{O}$ \\
\hline \multirow[t]{3}{*}{ Carangidae } & Caranx spp. & Caranx spp. & & $\mathrm{P}$ \\
\hline & Caranx ruber & & & $\mathrm{P}$ \\
\hline & & $\begin{array}{l}\text { Elagatis } \\
\text { bipinnulata }\end{array}$ & & $\mathrm{P}$ \\
\hline Scorpaenidae & $\begin{array}{l}\text { Scorpaena } \\
\text { plumieri }\end{array}$ & & & C \\
\hline
\end{tabular}

enteritic. Bile contained Ceratomyxa sp. spores. The posterior intestine contained amoebae (not identified to genus) and diplomonad flagellates. Partially digested Caulerpa racemosa var. peltata was the major food item in the stomach contents. Histological sections of ceca and anterior intestine showed excessive sloughing of the epithelial layer, necrotic and karyorrhectic nuclei of the epithelial cells, and basic loss of integrity of the intestinal epithelium down to the basal lamina (Fig. 3). External to the basal lamina, the muscular layer was intact (Fig. 4). In certain pockets of detached and detaching epithelial cells, large numbers of bacteria were present, usually adjacent to the basal lamina (Figs. 3, 4, 5, 6 $\& 7)$, and intracellular amoebae were scattered throughout the epithelium (Figs. 5, 6, 7\& 8). Amoebae were distinguished by having a light-mauve cytoplasm and a deep-mauve nucleus (in thionin-stained tissue) having peripheral heterochromatin (usually in 4 areas, Fig. 8). Amoeba-like cysts (staining light blue and having vacuoles in thionin) were also present, often in the lumen of the intestine. pulchellus (Fig. 1). Diseased fish typically had lesions on the anterior part of the head (Figs. $1 \& 2$ ), hemorrhaging (Fig. 2), ulcerated body sores, fin and tail rot (Fig. 1), and a heavy mucus coating on the body surface (Fig. 1). The severity and degree of the disease syndrome varied in different fish species. French and grey angelfish and rock beauties were the most commonly affected (Table 1).

Skin and gill scrapes from the grey angelfish examined on site in Boynton Beach had Uronema marinum and low levels of Brooklynella hostilis. Gills also had heavy levels of unidentified bacteria. Fin scrapes had a Cryptobia-like parasite, and there was localized hemorrhaging on the body. Barely digested Caulerpa racemosa var. peltata was found in the stomach and formed a large, partially digested bolus in the posterior intestine. Small amounts of sponges and Codium sp. (P. Hall \& K. Steidinger pers. comms.) were also found in the digestive tract. Bile contained spores of the myxosporean Ceratomyxa sp. Approximately 50 digenean trematodes were found in the posterior intestine.

The necropsied grey angelfish had a gill infestation of Brooklynella hostilis and one specimen of Lepeophtheirus sp. Fluid in the intestine was copious and
Table 3. Reef fish families not affected during the recent disease and mortality events (1980 to 1994), arranged by diet

\begin{tabular}{|c|c|}
\hline \multicolumn{2}{|l|}{ Planklivore } \\
\hline Atherinidae & Clupeidae \\
\hline Carangidae & Engraulidae \\
\hline \multicolumn{2}{|c|}{ Benthivore/Carnivore/Detritivore } \\
\hline Antennariidae & Holocentridae \\
\hline Apogonidae & Inermiidae \\
\hline Aulostomidae & Malacanthidae \\
\hline Batrachoididae & Muraenidae \\
\hline Belonidae & Ogcocephalidae \\
\hline Bothidae & Ophichthidae \\
\hline Callionymidae & Opistognathidae \\
\hline Centropomidae & Pempheridae \\
\hline Cirrhitidae & Priacanthidae \\
\hline Clinidae & Rachycentridae \\
\hline Congridae & Sciaenidae \\
\hline Dactylopteridae & Scombridae \\
\hline Elopidae & Syngnathidae \\
\hline Exocoetidae & Synodontidae \\
\hline Fistulariidae & Tetraodontidae \\
\hline Gerreidae & Triglidae \\
\hline Gobiidae & Uranoscopidae \\
\hline
\end{tabular}

Grammistidae 


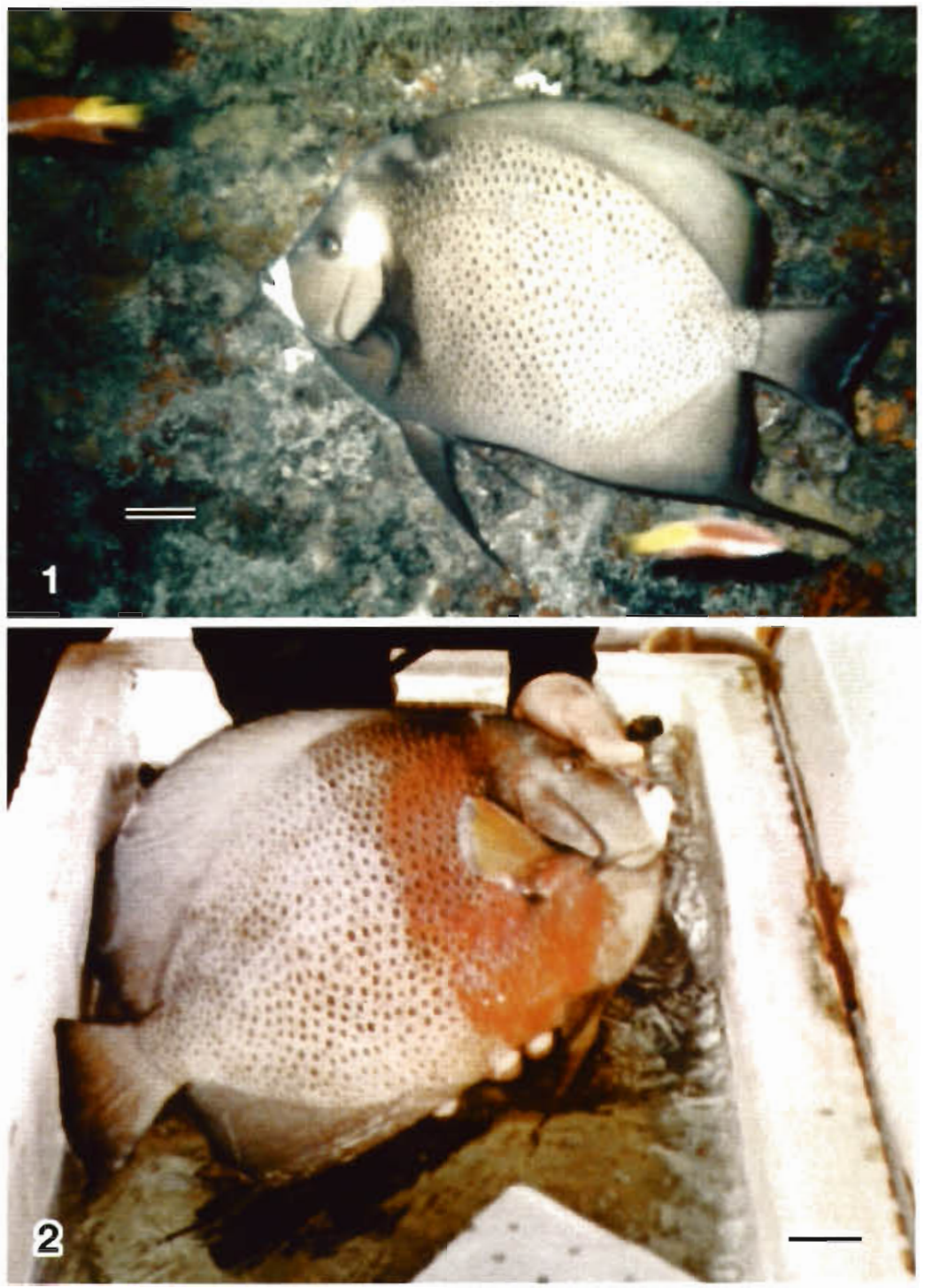

Figs. 1 to 2. Diseased grey angelfish Pomacanthus arcuatus. Fig. 1. Fish with lesions on front of head and caudal fin. Cleaner spotfin hogfish Bodianus rufellus present. Photographed 15 December 1993 at $30 \mathrm{~m}$ depth on Sail Buoy Reef, Briney Breezes, Palm Beach, Florida, USA (courtesy B. Parks). Scale bar $=4.0 \mathrm{~cm}$. Fig. 2. Moribund grey angelfish with severe hemorrhaging on the anterior body. Photographed 18 December 1993 above Briney Breezes, Palm Beach (courtesy S. Hindley). Scale bar $=3.5 \mathrm{~cm}$

The necropsied French angelfish had an extremely heavy infestation of Brooklynella hostilis on the gills and lesions on the head region, anterior body, and dorsal fin. The intestine was enteritic and had a heavy amoeba infestation. Pathology was similar to that of the grey angelfish.

Tissues from both necropsied angelfish were negative for ciguatoxin (by ELISA assay sensitive to brevetoxin and ciguatoxin; D. Baden pers. comm.).

Examination of fish from the Islamorada area revealed no remarkable pathology or parasitic infesta- tions. The balloonfish had external turbellarian infestations with encapsulated adult worms just below the epithelial layer of the body. Bacteriology of the ulcerated fin lesion of the reef butterflyfish revealed the presence of mixed Vibrio ( $V$. pelagius II and $V$. damsela), 3 Aeromonas spp., and a Pseudomonas sp. (J. Pallias pers. comm.). The kidney was negative. Squash preparations of the intestine contained amoebae.

Gambierdiscus toxicus was present in scrapes of reef-plant material. Water and sediment samples were negative for dinoflagellates ( $K$. Steidinger pers. comm.).

Histological sections of Holacanthus bermudensis gills from the 1980 fish kill showed heavy infestations of Brooklynella hostilis (Figs. 9, 10 \& 11), increased concentration of chloride cells (Fig. 11), detachment of the gill epithelium (Fig. 11), granulomas (Fig. 12), hypertrophy and fusion of the secondary lamellae (Fig. 13), and epitheliocystis (Fig. 13). In addition, unidentified helminths were found in sections of blood vessels behind the cartilage of the gill arch (Fig. 14) and between the secondary gill lamellae (Fig. 15). Large numbers of amoebae were found in the stomach epithelium. Intestinal pathology was very similar to that observed in the grey angelfish from the 1993-94 kill described above.

\section{DISCUSSION}

In the 1980 reef-fish kills in both Florida and the Caribbean, no one specific agent or chain of events explained the heavy losses. Red tide, toxaphene dumping, upwelling and associated cold temperatures, and infestations of parasites such as Brooklynella hostilis, Cryptocaryon irritans, and Amyloodinium ocellatum were all proposed (Atwood 1981).

The chronic nature of the 1993-94 incident provided an ideal opportunity to study a relatively long-term natural outbreak of disease in a marine environment. Usually, when fish kills occur, they are caused by acute stressors such as algal blooms, low dissolved oxygen, or contaminant spills, and short-term but heavy mortalities are typical. Even when chronic stressors or disease 

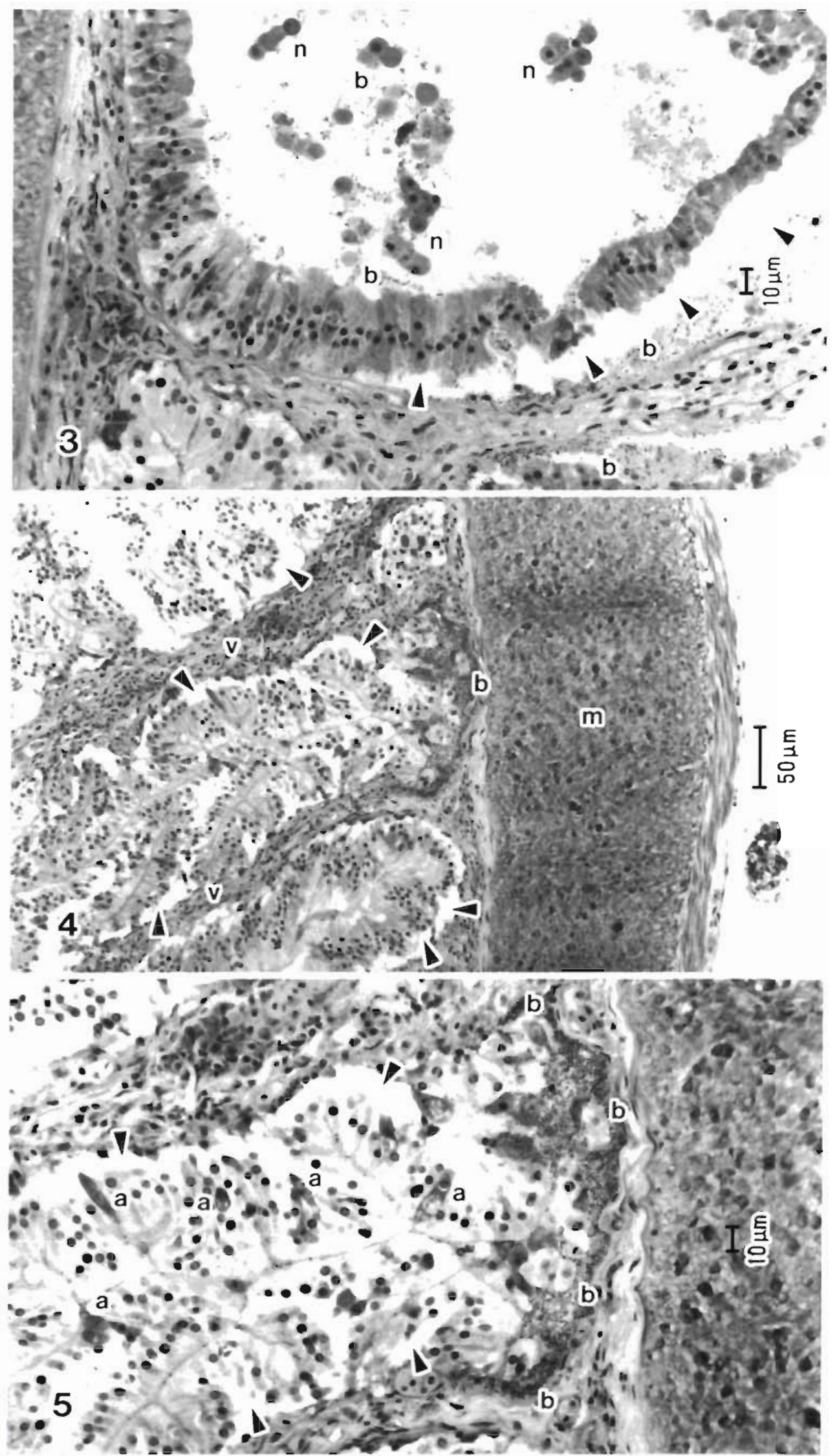

Figs. 3 to 8. Pomacanthus arcuatus. Histological sections of grey angelfish intestine from 1993-94 fish kill. All slides stained in thionin. Fig. 3. Sloughed and necrotic epithelial cells (n), bacteria (b) in the lumen and along the basal lamina, and epithelial detachment (arrows) from the lamina propria. Fig. 4. Villi (v) detached epithelial lining at the basal lamina (arrows). bacteria (b), and intact muscle (m). Fig. 5. Detached epithelial lining (arrows), bacteria (b) at the basal lamina, and amoebae (a) in epithelial cells 


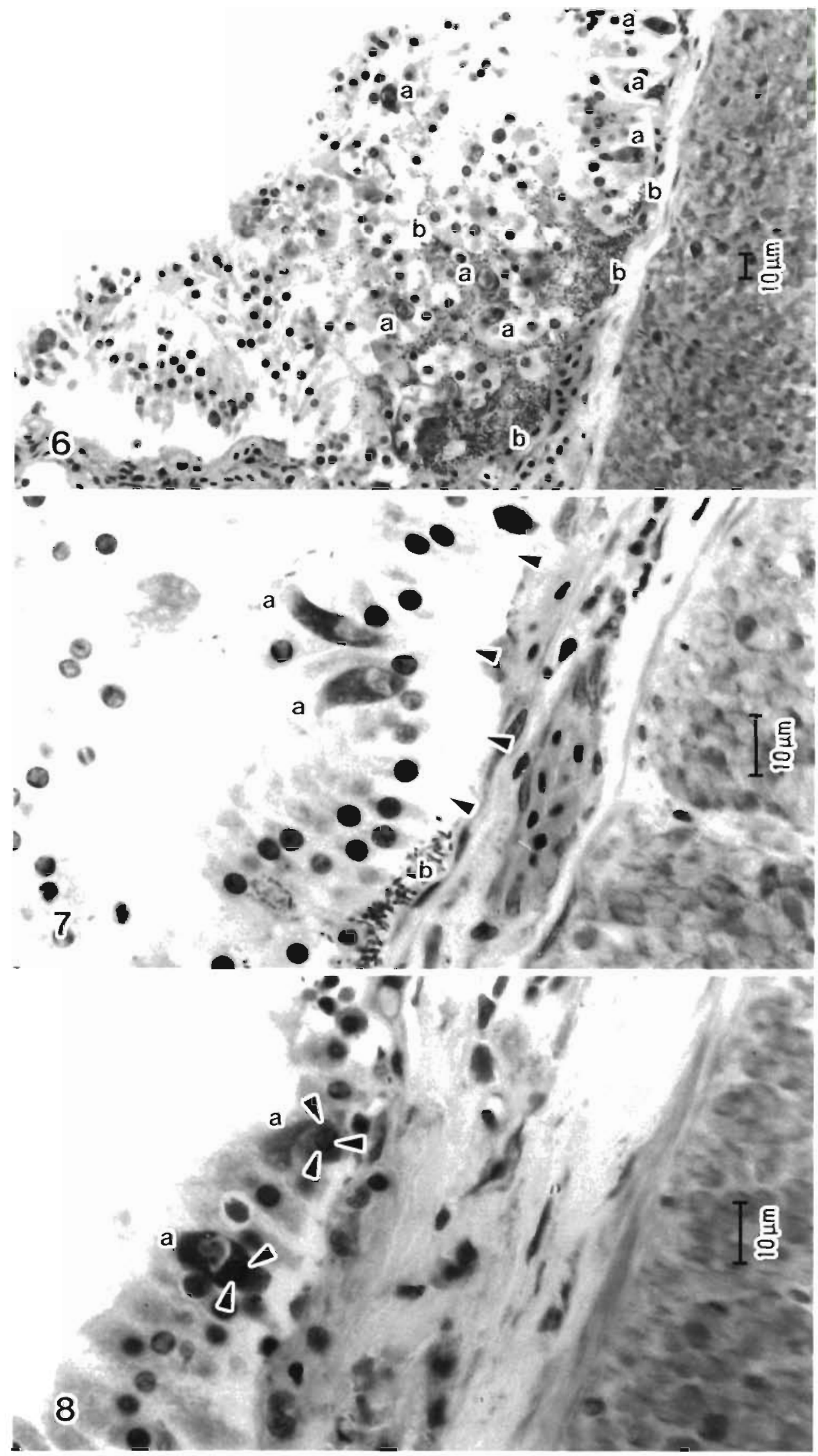

Fig. 6. Masses of bacteria (b) at the junction of the epithelium and the basal lamina and amoebae (a) in swollen and vacuolate epithelia cells. Fig. 7. Higher magnification showing detaching epithelial cells (arrows), 2 amoebae (a) in the epithelia cells, and bacteria (b) at basal lamina and amongst necrotic epithelial cells. Fig. 8 . Higher magnification of 2 amoebae (a) showing periph eral heterochromatin (arrows) in the nucleus

\section{8}



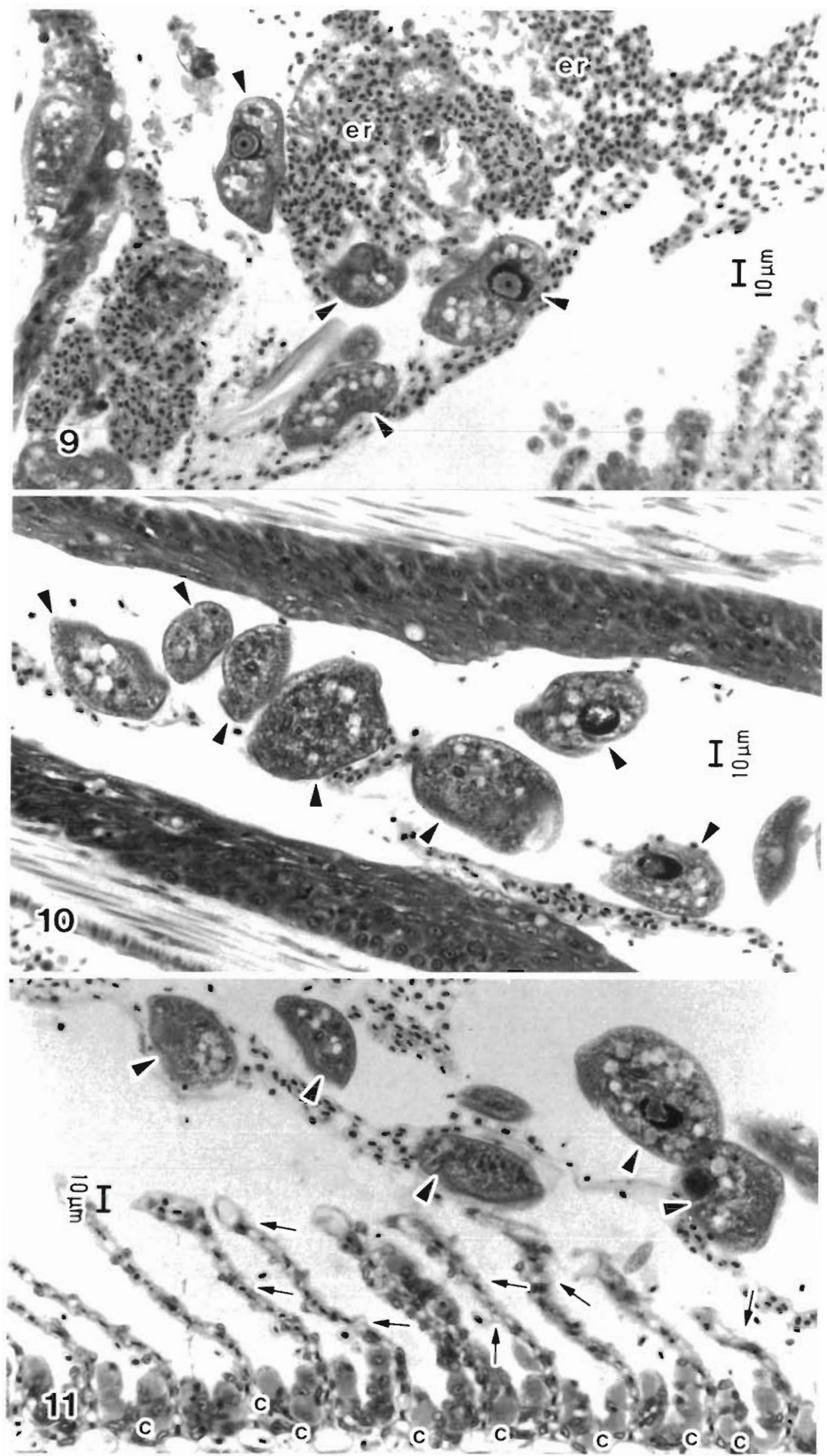

Figs. 9 to 15. Holacanthus bermudensis. Histological sections of blue angelfish gills from 1980 fish kill. All slides stained in thionin Fig. 9. Brooklynella hostilis (arrowheads) and erythrocytes (er). Fig. 10. B. hostilis (arrowheads) between the primary gill lamellae. Fig. 11. B. hostilis (arrowheads) above the secondary gill lamellae. Note increased numbers of chloride cells (c) and detaching epithelial cells (arrows) (may be fixation artifact) 


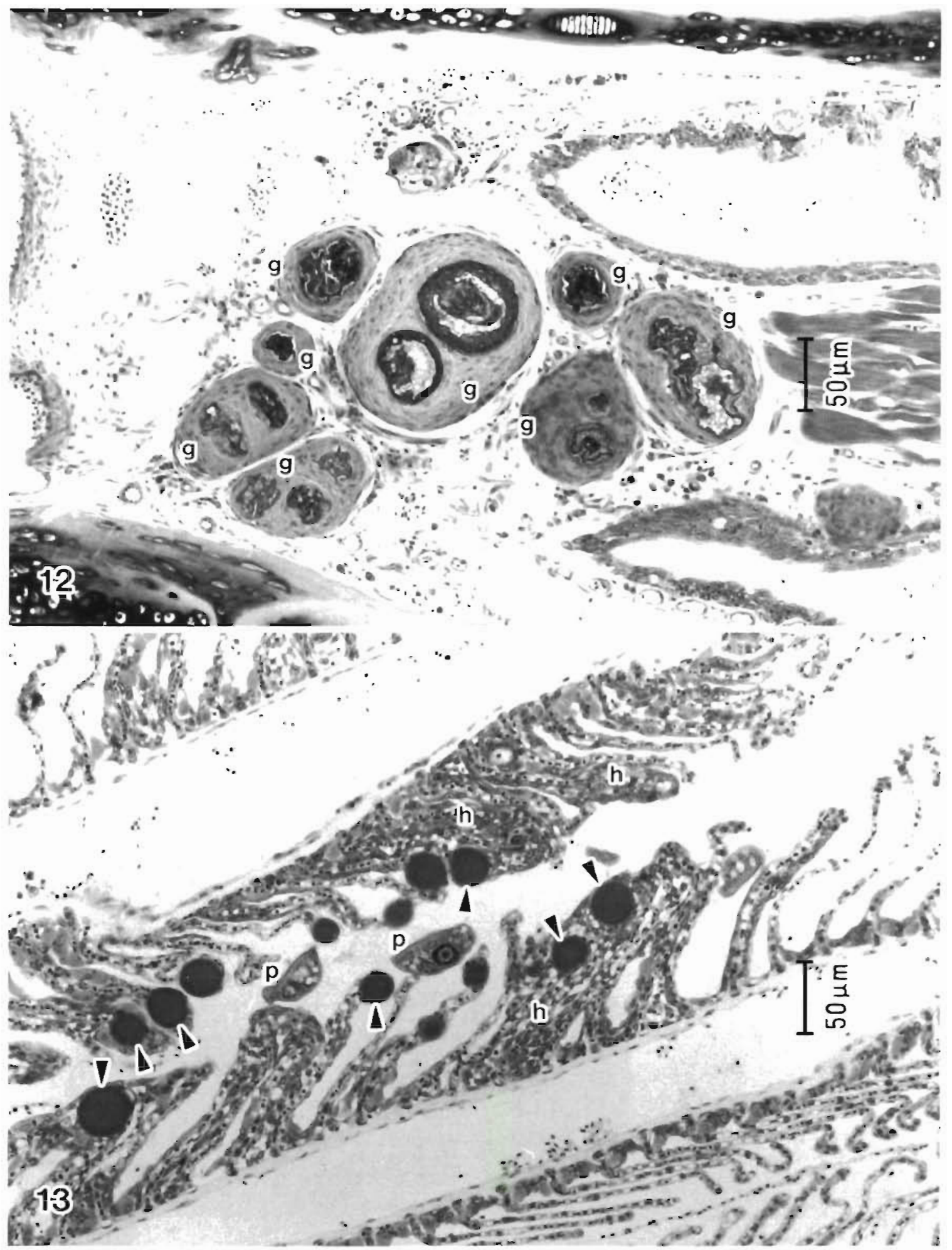

Fig. 12. Multiple granulomas (g) at the base of the gill cartilage. Fig. 13. Epitheliocystis (arrows), a few Brooklynella hostilis (p), and fusion and hypertrophy (h) of secondary lamellae (continued on next page) 


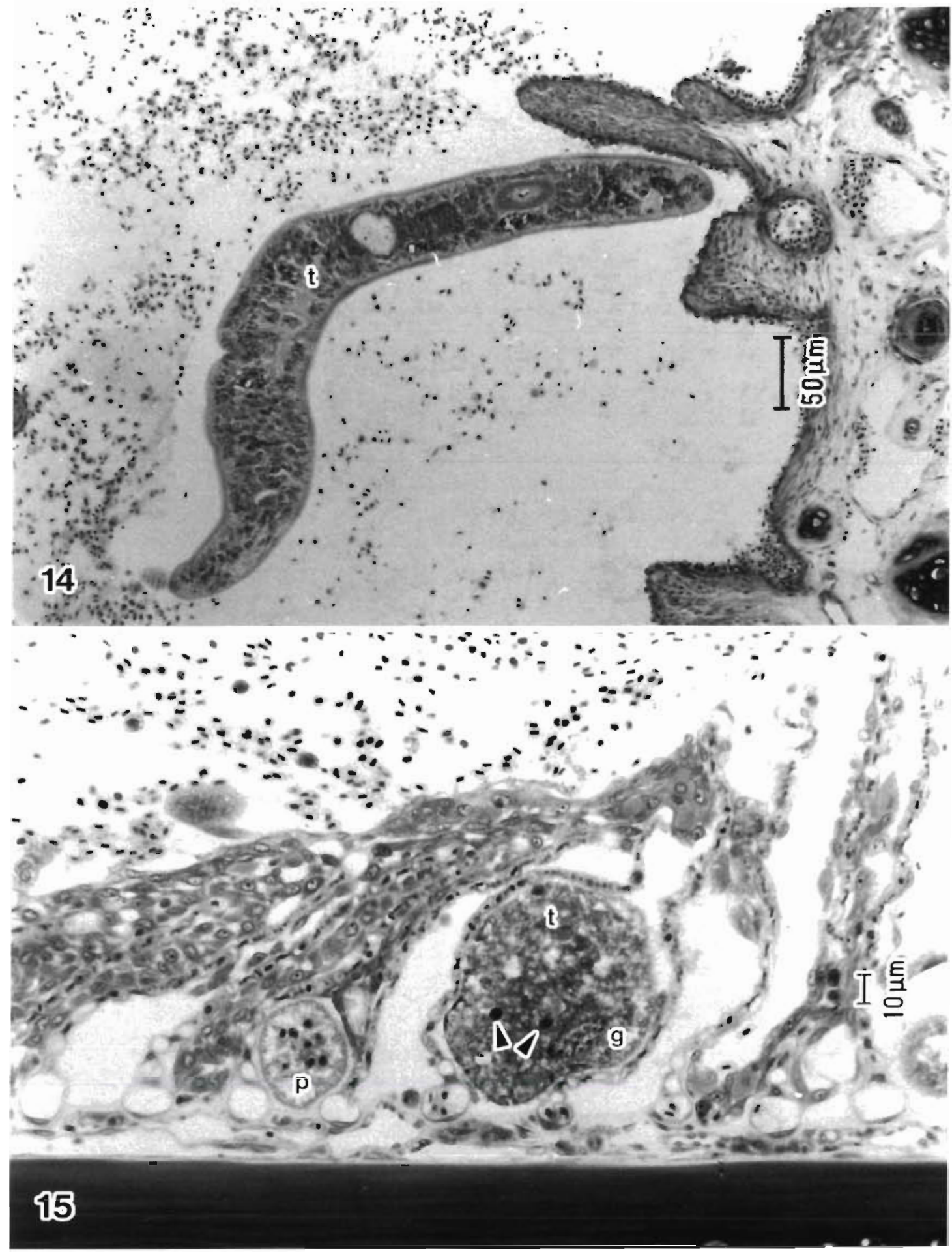

Figs 9 to 15 (continued). Fig. 14. Longitudinal section of an identified helminth (t) in blood vessel at the base of the gill arch. Fig. 15. Helminth (t) in blood vessel and a Brooklynella (p) in cross section between the secondary lamellae. Note the 2 eyespots (arrows) and gonad $(\mathrm{g})$ of the helminth 
affect a marine fish population, dying or dead fish may be quickly removed from the affected area by predation, wind, or prevailing currents. Detection of such disease outbreaks is rare unless they occur close to shore or, as in this case, in areas frequented by divers

High numbers of several ectoparasite species were detected on some fish from both the 1980 and 1993-94 Florida disease outbreaks. In 1980, diseased fish that were brought from the Florida Keys and held in aquaria for a few days apparently succumbed to Cryptocaryon irritans (from the collector's tank? Burns 1981). My reexamination of archival tissues showed only heavy gill infestations of Brooklynella hostilis (Figs. 9, 10, 11, 13 \& 15). Adult ciliated turbellarians may have been misinterpreted in 1980 as being large ciliated forms of $C$. irritans. In 1993-94, the few fish examined directly from the reef had low-level infestations of ectoparasites, yet those held in the lab for a few days had heavy infestations of $B$. hostilis. In stressed wild fish, or in fish held after capture, some species of parasites are likely to increase in numbers within a few days

Ectoparasitic protists are typically found in low numbers on fish under natural conditions and cause few or minor pathogenic effects. When wild fish are weakened by other stressors, or introduced into aquaria without treatment and quarantine procedures, particularly if the fish are already severely stressed or diseased, some opportunistic parasite species may increase in number, become pathogenic, and kill the fish. Brooklynella hostilis has been described as being an extremely pathogenic parasite in closed aquarium systems (Lom \& Nigrelli 1970). On the other hand, Uronema marinum, a normally free-living ciliate found on the diseased fish in 1993-94, usually only invades fish that are already compromised by some type of environmental stress, at which time it may become a facultative parasite and cause mortality (Cheung et al. 1980). Typical external signs of $U$. marinum on the fish are white patches that eventually develop into lesions or open wounds. Fish become nervous, are listless, and breath heavily (Lom \& Dyková 1992). Diseased fish on the reef having mixed parasite and bacterial infestations displayed many of these signs.

Adult turbellarians are often found encapsulated under the epidermis of tropical reef fish, such as rock beauties, in Florida (Landsberg unpubl.) and the Caribbean (Grizzle \& Williams 1985). Turbellarians have been implicated in disease and mortality in aquaria (Kent \& Olson 1986), but there is no evidence that they cause disease in natural situations (Cannon \& Lester 1988).

In tropical reef systems, ectoparasitic infestations of fish may be partially controlled by cleaner fish. Parasitized fish typically frequent cleaning stations (Gorlick et al. 1987) where fish such as wrasses, gobies, and
Spanish and spotfin hogfish pick off ectoparasites. The number of diseased fish and the frequency at which they appeared at the cleaning stations were higher than normal during the latest disease event (B. Parks pers. comm.). After mortalities ceased, spotfin hogfish were apparently rare at these sites (C. Parks pers. comm.)

Although gill pathology of the diseased angelfish was principally associated with parasites, the intestinal pathology, including fluid accumulation, epithelial sloughing and detachment down to the basal lamina, appears to indicate the presence of a toxic mechanism. For example, Capra et al. (1988) noted degeneration of the lamina propria, swelling of the villi tips, and absence of the brush border in the intestine of ciguatoxin-exposed fish Chromis nitida. Presence of biological toxin may lead to epithelial sloughing that in turn allows a portal for entry of amoebae and bacteria. There were heavy intestinal infestations of amoebae and bacteria in the diseased angelfish. Whether these pathological changes were caused by biological toxins, amoebae, bacteria, or a combination of these needs to be clarified. Amoebiasis in fish results from opportunistic pathogenesis associated with immunosuppression. Although symbiotic Entamoeba occur in the intestine of a few marine fish species, it is rare to find amoebae in fish unless typical amphizoic (free-living) forms become pathogenic or parasitic (Lom \& Dyková 1992). Bacteria and sloughed mucus cells in the fish intestine would provide an ideal food source for amoebae (Lom \& Dyková 1992). Herbivorous fish are known to have active, symbiotic, intestinal bacterial and flagellate populations that play a role in digestion, but the presence of symbiotic amoebae has not been documented. Intestinal protists have been reported in acanthurids (Grim 1988, Clements et al. 1989, Basson et al. 1990). It is unknown whether the gut organisms noted in the present study are part of a normal gut flora that may become pathogenic under certain conditions.

In recent years, the association of amoebiasis with epizootics and mortalities of aquatic organisms has emphasized our relative lack of knowledge about the pathogenesis, epizootiology, and ecology of these amoebae (Jones 1985, Kent et al. 1988). Of some concern is the potential transmission of normally freeliving amoebae to marine organisms and their apparent switch to pathogenic forms in stressed hosts. Are coastal areas becoming more 'amoebae-tolerant' as a result of increased sewage loads in near-shore environments? Some amoebae are pathogenic to humans, but there is little information about the potential transmission of these amoebae to marine organisms. The presence of some amoebae species in polluted habitats is an indicator of declines in ecosystem health (Sawyer 1980). 


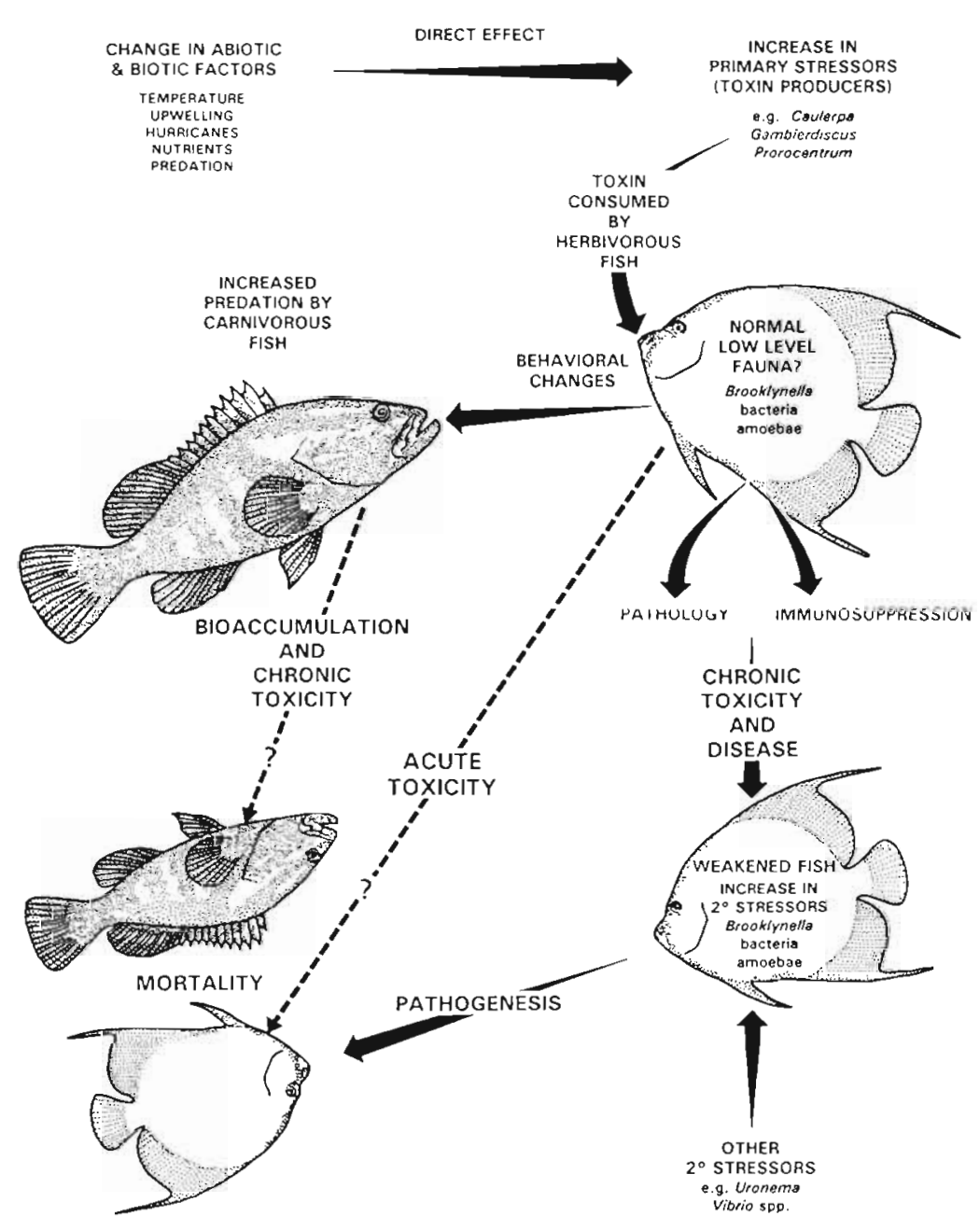

Fig. 16. Food chain hypothesis for the series of events in the Florida reef fish kills, indicating major primary and secondary $\left(2^{\circ}\right)$ stressors

synergy with these natural events, the reef system could have been affected by natural or anthropogenic changes in the aquatic environment. Influences leading to substantial increases in the extent of algal cover on the reef include increased sewage output, sedimentation, high nutrient levels stimulating macroalgal growth, and overfishing and associated declines in herbivory (Pastorok \& Bilyard 1985, Lapointe 1989, Hughes 1994). These affects may also have contributed to changes in the distribution or increases in the number of toxic benthic dinoflagellates on the reef.

If there are cyclical changes in the distribution of potential biotoxic organisms or bioaccumulation in the fish, then there may be a connection between the food preferences of the fish species affected and the level of toxin found. The fact that disease and mortality among affected fish was greatest in adult herbivores or omnivores could suggest dietary accumulation of a biological toxin; such a chronic stressor could render fish susceptible to disease. Juvenile fish of the affected species may have a different diet, or perhaps bioaccumulation of the toxin merely requires a longer period. Biological toxins could be ingested by fish either through direct consumption of toxic macroalgae (e.g. Caulerpa) or by indirect consumption of toxic epiphytic dinoflagellates (such as Gambierdiscus toxicus, Prorocentrum spp. or Ostre-

In Florida, no extensive reef-fish mortalities were documented between 1980 and the 1993-94 event. Why reef-fish mortalities have appeared or reappeared in Florida remains unknown. In diseased or dying fish sampled directly from the reef, multiple pathogens were present but no primary pathogen was identified. Unknown stressors may have severely weakened the fish, which were then susceptible to a number of secondary, opportunistic parasites and bacteria. Primary stressors, particularly sublethal dietary biotoxins, that may have led to disease and subsequent mortalities could be postulated (Fig. 16). A number of scenarios could be proposed that may have created a 'domino effect' that led to increases in the number of such biotoxic organisms. Perhaps a series of natural events, beginning with an event like Hurricane Andrew or flooding in the Mississippi Delta, may have led to changes in the successional colonization or cover of macroalgae on the coral reefs. Alternatively, or in opsis). Piscivores or cleaner fish could then accumulate toxin by preying on affected herbivores or parasites. Comparison of the diets of fish affected during both the 1980 and 1993-94 Florida and Caribbean kills (Tables $1 \& 2$ ) would tend to suggest that a common biotoxin with a wide distribution would more likely be a primary stressor. For example, benthic dinoflagellates are distributed on a wide range of food items and substrates. Because many species of fish with different dietary preferences were affected, it is likely that a broad spectrum biotoxin would be involved.

Macroalgae on coral reefs have adaptive mechanisms such as the production of secondary metabolites that discourage predation by herbivores (Littler et al. 1983, Paul 1987). Feeding-preference studies and stomach-content analyses of fish and sea urchins (Paul $\&$ Fenical 1986) have shown that caulerpalean algae are usually considered to rank low in dietary preference. In Caulerpa spp., a major secondary metabolite, 
caulerpenyne, is toxic to fish, sea urchin eggs, conch, and microorganisms, or acts as a feeding deterrent to molluscs, sea urchins (Targett \& Mitsui 1979, Paul \& Fenical 1986), and some fish (Meyer \& Paul 1992). Caulerpenyne is specifically toxic to Gambusia affinis at $10 \mu \mathrm{g} \mathrm{ml}^{-1}$ (Gavagnin et al. 1994) and to the damselfish Pomacentrus coerulus and Eupomacentrus leucostictus at $20 \mathrm{\mu g} \mathrm{ml}^{-1}$ (Paul \& Fenical 1986). When given only Caulerpa mexicana from a choice of seagrasses and algae, the parrotfish Sparisoma radians died after $20 \mathrm{~d}$. Parrotfish given their preferred foods, such as Thalassia and Syringodium, survived for the 40 d experimental period (Lobel \& Ogden 1981).

Other organisms are also affected by Caulerpa toxicity. In feeding assays, $70 \%$ of juvenile conch Strombus costatus died within $14 \mathrm{~d}$ after being fed Caulerpa, whereas $100 \%$ survived when fed Enteromorpha (Lobel \& Ogden 1981). Juvenile green turtles Chelonia mydas in Hawail will feed on Caulerpa racemosa only when their preferred algal foods are absent. Although Caulerpa is apparently not toxic to these turtles, growth rates of turtles feeding on it were less than those for turtles from other Hawaiian Islands that fed on their preferred algae (Balazs 1982). It would be interesting to determine if there is any connection between disease susceptibility, such as the noticeable increase in fibropapillomas in green turtles in Florida waters (A. Meylan pers. comm.) and the Caribbean region (Williams et al. 1994), and low-level feeding on Caulerpa or other toxic macro- or microalgae. The absence or decline of preferred foods such as Thalassia, which recently occurred as a result of the seagrass die-off in Florida Bay (Robblee et al. 1991), may cause turtles to switch to a different and perhaps potentially toxic diet.

Grey and French angelfish and rock beauties feed principally on sponges (Randall \& Hartman 1968, Neudecker 1985), but algae can comprise 10 to $50 \%$ of the diets with the remainder comprising sponges (Hourigan et al. 1989). In algal-choice experiments, the Pacific angelfish Centropyge flavissimus preferred Caulerpa racemosa, but grey angelfish preferred Codium (Ogden \& Lobel 1978). Some fish may therefore feed upon Caulerpa preferentially or when other foods are not available. This latter situation may have been the case on the reefs from which kills were reported. From 1989 to 1992, reefs in the Palm Beach region were covered with heavy Codium mats (Carlson \& Barber 1994). In late 1992, changes in macroalgal cover were reported when a decline in the dominance of Codium was apparent (B. Parks pers. comm.). The decline in Codium in the Palm Beach area this past year may have induced increased feeding on Caulerpa, as evidenced by the presence of large quantities of Caulerpa sp. in the intestinal tract of the angelfish from the 1993-94 mortality event. If, because Caulerpa is not a normal component of the angelfish diet, no appropriate detoxification mechanisms are present, then continued feeding upon this alga may induce a sublethal toxicity in the fish. Chronic exposure to these toxins may render fish susceptible to opportunistic fish pathogens.

Caulerpenyne has antimicrobial properties that may create an imbalance in the normal microbial gut flora of tropical reef fish, making them more susceptible to pathogens. In many cases, normal components of the gut flora of tropical reef fish are potentially pathogenic bacteria, such as Vibrio damsela, $V$. harveyi, and Photobacterium leiognathi (Sutton \& Clements 1988), that may become opportunistic pathogens in stressed fish (Love et al. 1981, Toranzo et al. 1993)

Gambierdiscus toxicus is normally found as an epiphyte on Caulerpa and other macroalgae, and in close association with sand, coral, sponges, or detritus (Anderson \& Lobel 1987). The presence of G. toxicus in scrapes of reef-plant material from the Palm Beach area constitutes a range extension record (K. Steidinger pers. comm.). Toxic benthic dinoflagellates Gambierdiscus toxicus, Prorocentrum spp., and Ostreopsis siamensis have been found farther south along the Florida coast and in the Keys (Bomber et al. 1988, 1989). These dinoflagellates are well known for their association with human ciguatera poisoning caused by consuming toxic fish in the Florida and Caribbean region (Swift \& Swift 1993). Ciguatera toxins are biomagnified and biotransformed during transfer through the food chain from herbivores that graze on toxic epiphytic dinoflagellates, to piscivores that feed on ciguateric herbivores, and finally to humans consuming ciguatoxic fish (Swift \& Swift 1993). Ciguatera toxins associated with benthic dinoflagellates are usually considered sublethal or lethal only at the top of the food chain, and the effect on humans (Swift \& Swift 1993) is well known (Anderson \& Lobel 1987). Some ciguatoxin precursors found in G. toxicus (e.g. gambiertoxins) (Holmes et al. 1991) are apparently transferred to, or transformed in, herbivorous fish and have changed into a more toxic form (ciguatoxin) in carnivorous fish (Legrand et al. 1992) by the time that they are available in fish muscle for human consumption. The possibility that angelfish may have ingested $G$. toxicus or Prorocentrum spp. while feeding on Caulerpa sp. or other substrates is highly likely.

Although benthic dinoflagellates were not detected in the stomach contents of the fish I examined, fish were held in the lab for several days and might have already digested or excreted such organisms. Or, if one exposure to toxin is sufficient to cause a pathological response in fish, then consumption of dinoflagellates may have occurred several days or weeks prior to 
examination. In addition, not all of the appropriate methods for detecting or distinguishing between different ciguatera toxins in fish tissues were used in the current investigation. No ciguatoxin was detected in angelfish muscle and liver from the 1993-94 kill (D. Baden pers. comm.). Recent evidence suggests that ciguatoxin would not necessarily be present in the same form in herbivorous fish, but only higher up the food chain in carnivorous fish (Legrand et al. 1992). Current methods will detect relatively low (nanomolar) concentrations of ciguatoxin in carnivorous fish (Legrand et al. 1992), but even lower concentrations of ciguatoxin or other toxins such as maitotoxin, scaritoxin or okadaic acid might have remained undetected in the herbivorous fish in this study. These toxins may be iethai or, if subiethai, cause stress and lender the fish susceptible to disease. In acanthurids that consumed heavy concentrations of Gambierdiscus toxicus, resulting in dramatic behavioral changes that indicated a toxic effect, Magnelia et al. (1992) could not detect ciguatoxin in muscle and liver tissues. Abnormal neurological behavior was reported in herbivorous fish that were exposed to $G$. toxicus in a coral reef microcosm, but again, ciguatera toxins could not be detected in muscle tissue ( $F$. van Dolah pers, comm.). It may be that the current testing methods used for known ciguateric toxins are not broad-spectrum enough to detect the whole suite of toxins that may be present in fish.

Ciguatera toxins were reported to have no effect on fish in the wild (Banner et al. 1966, Swift \& Swift 1993), yet experiments have shown that ciguatera toxins can be lethal to fish (Capra et al. 1988, Durand-Clement et al. 1987 cited in Gonzalez et al. 1994, Lewis 1992). Experimentally induced pathological changes in the gills, liver, and intestine of fish were associated with the ingestion of Gambierdiscus toxicus (Capra et al. 1988, Gonzalez et al. 1994). Experiments have clearly shown that the behaviour of crustaceans and fish changes after these organisms feed on either ciguatoxic flesh or directly on $G$. toxicus cells. Fish show abnormal behaviours such as erratic movement, disorientation, blanching of skin, loss of both equilibrium and appetite (Davin et al. 1986, 1988, Kohler et al. 1989, Kelly et al. 1992, Magnelia et al. 1992). Tilapia fed different stains of $G$. toxicus showed a differential response ranging from death within $24 \mathrm{~h}$ to abnormal swimming behavior, quiescence, loss of both equilibrium and appetite. Fish showing minimal toxicity recovered 21 d after the original dose was administered (Kelly et al. 1992). These behaviors and signs are like those seen in diseased fish during the 1993-94 mortality (B. Parks pers. comm. and video footage), and $G$. toxicus was present in scrapes of plant material taken at that time.
Ciguatera toxicity has been confused with toxicity from caulerpenyne. Human illness due to 'ciguatera' was suspected in Israel in individuals who ate a marine fish, the saupe Sarpa salpa (Spanier et al. 1989), but the fish had fed on Caulerpa sp. (Chevaldonné 1990). Since human toxicity symptoms after eating such fish are similar to those of ciguatera, the toxic effects (if any) to fish may also be difficult to discriminate. Caulerpa is toxic to the saupe, but because preferred food items are not always present during certain periods due to climatic or competitive processes (Chevaldonné 1990), the saupe, like perhaps the angelfish, at times has no alternative diet. The effect of Caulerpa or $G$. toxicus alone or acting synergistically (Vidal et al. 1984) in fish should be discriminated.

Tlue cyanobacterium Trichodesnium erythraeum was recently associated with a food-chain hypothesis linking it with clupeids and narrow-barred Spanish mackerel in ciguatera-like outbreaks in Australia (Hahn \& Capra 1992, Endean et al. 1993). Although blooms of $T$, erythraeum were recorded during the 1980 Caribbean kills (Atwood 1981), no direct link has established the potential role of $T$. erythraeum in fish mortalities. Trichodesmium sp. has been associated with coral polyp mortalities (Endean 1977) and was recently found at the site of a coral bleaching (Coles 1994). Randall (1958) postulated a connection between clupeid poisoning in humans, mortalities of shallowwater fish and invertebrates and Trichodesmium sp. After an unusual number of marine mammal mortalities in North Carolina, blooms of Trichodesmium sp. were documented, and in laboratory experiments, Trichodesmium sp. was found to be toxic to the copepod Acartia tonsa (Guo \& Tester 1994). This indirect evidence suggests a relationship between Trichodesmium $\mathrm{sp}$. and marine mortalities, but it is still unclear whether blooms of these cyanobacteria produce toxins that are lethal to marine organisms in the wild.

Since 1980, there have been recurring mass mortalities of Caribbean herrings Harengula spp. (Williams \& Bunkley-Williams 1990a), but no definitive explanation has yet been found. In this type of event, a disease specific to a genus or family would be considered because mortality related to environmental factors would not generally be selective for one family of fish. High levels of toxin accumulated through the food chain might explain these kills. White $(1981 \mathrm{a}, \mathrm{b}, \mathrm{c})$ and White et al. (1989) showed that zooplankton that had consumed the dinoflagellate Alexandrium excavatum were toxic to Atlantic herring Clupea harengus and were implicated in widespread herring kills. Fish swam abnormally and became immobilized 10 to 20 min after toxin extracts of $A$. excavatum were administered (White $1981 \mathrm{~b}$ ). In 5 separate cases of mass herring kills in the Caribbean, Williams \& 
Bunkley-Williams (1990) noted that herring were observed swimming near the surface and were lethargic

Mortalities associated with concentration of toxins up the food chain from microalgae through fish have also involved mammals and birds. Humpback whales died after eating Atlantic mackerel containing saxitoxin, which causes paralytic shellfish poisoning (PSP) in humans (Geraci et al. 1989). PSP and domoic acid were also implicated in kills that occurred after birds fed on toxic fish (Coulson et al. 1968, Work et al. 1993).

The mass mortalities in Florida and in the Caribbean in 1980 and in the 1993-94 kill in Florida involved reef fish that are principally herbivorous or that are involved in a food chain that could be potentially associated with the transfer of biological toxins. The concept of biological toxins being transferred through the food chain is not new, but no consideration has been given to sublethal, toxic effects that may render aquatic organisms stressed, immunosuppressed, and susceptible to a whole range of opportunistic pathogens. If the toxins were active in the water rather than transferred selectively through the diet, then most aquatic organisms in the region of a toxic bloom would be affected, rather than the relatively small number of species that appear to be involved in the current series of mortalities. Could a dietary hypothesis explain the heavy Caribbean-wide die-off of the longspined sea urchin Diadema antillarum (1983-84) and the incidence of fibropapillomas in green turtles?

The sudden appearance of biological toxins in natural systems is most commonly associated with blooms of algae that are principally planktonic and acutely toxic. Changes in the abundance and distribution of benthic toxic organisms around a coral-reef community may explain the cyclical nature of ciguatera as well as the apparent cyclical nature of mass mortalities of aquatic organisms not otherwise explained by environmental perturbations. For example, Bagnis et al. (1990) found in Tahiti that after 13 yr of stable, low levels of the toxin-producing Gambierdiscus toxicus (predominantly epiphytic on Jania sp.) there was a sudden increase in the population of this dinoflagellate within a 3 wk period, and fish became ciguatoxic shortly thereafter.

Of course, little is known about cyclical phenomena and the effect of mass mortalities on grazing and dominance changes - or vice versa - in the benthic community of a coral reef. Ultimately, these successional changes may be part of a longer-term natural cycle of which we are currently unaware. The recent series of coral-bleaching events may also affect algal colonization. Kohler \& Kohler (1992) showed that newly bleached coral-reef surfaces were immediately recolonized by filamentous algae with attached epi- phytic dinoflagellates of the genera Gambierdiscus, Ostreopsis, and Prorocentrum. Gambierdiscus toxicus is usually the first colonizer of opportunistic macroalgae or substrates after natural or manmade disturbances (Anderson \& Lobel 1987). The mass mortality in the Caribbean in September 1980 followed Hurricane Allen, the path of which almost bisected the reported fish-kill distribution. Those mortalities could have been related to substrate recolonization by toxic algae. However, this theory would not explain the 1980 fish kill in Florida that occurred prior to the hurricane. The temporal and spatial distribution of toxic benthic dinoflagellates, ciguatera outbreaks, reef-fish kills, and other disease outbreaks and mortalities in the Caribbean and off the coast of Florida should be compared. The potential toxic effect of benthic dinoflagellates or Trichodesmium erythraeum upon symbiotic dinoflagellates (zooxanthellae) in corals and the relationship (if any) of these toxins to coral disease and bleaching should also be investigated.

In conclusion, I cannot point to any one primary causative agent for the 1993-94 fish kills in Florida Healthy fish were probably affected by a sequence of events (Fig. 16), which most likely included abiotic or biotic changes leading to increased abundance of toxic micro- or macroalgae and an early, sublethal toxicity caused by chronic consumption of macro- or microalgae such as Caulerpa sp. or Gambierdiscus toxicus and proceeded through sloughing of the intestinal epithelium (possibly as a result of a biological toxin), immunosuppression, amoebiasis or bacterial infection, further intestinal pathology, weakening of the fish, further parasitic infestation by Brooklynella hostilis and other opportunistic parasites or bacteria and finally parasite pathogenesis leading to mortality. A similar series of events, possibly initially associated with a bloom of Trichodesmium sp., could have caused the mortalities in Florida and in the Caribbean in 1980

Although part of this discussion has been speculative, I feel that it is critical to evaluate the potential involvement of dietary biological toxins in disease and mass mortalities of aquatic organisms. There are a number of ecological interactions that need to be clarified during such an evaluation. The sequence of events in which natural or anthropogenic physical or biological phenomena affect the colonization process of toxic organisms needs to be determined; related changes in the succession of macroalgae and associated changes in herbivory need to be studied, as does the effect of those changes on organisms in the food web; and finally, aquatic mass mortalities and diseases must be studied within an overall ecological framework. Completion of such detailed studies will take years. Meanwhile, there is a pressing urgency to at least establish and integrate a reef-fish disease monitoring program 
with other reef-ecosystem, fisheries, and aquaticmortality studies being conducted in the Gulf of Mexico and the Caribbean. The information presented in the present study could also have important implications for fisheries management.

Acknowledgements. I thank Bill and Chris Parks of Boynton Beach, Florida, for bringing the disease outbreak to my attention, for assisting in the collection of diseased fish, and for sending excellent video footage; William Sabat of Islamorada for shipping live fish; and Dan Baden of the Rosenstiel School of Marine and Atmospheric Science, University of Miami, for testing liver and muscle of angelfish for ciguatoxin. I thank the following staff at the Florida Marine Research Institute Karen Steidinger and Penny Hall for identifications; Bev Roberts for 1980 Florida fish kill information; Pam Nagle James Pallias, Noretta Perry and Paul Forstchen for technical support; Barb Blakesley for the drawing; and Ruth Reese Judy Leiby, Jim Quinn, and Llyn French for their comments and critique of the manuscript. Special thanks to Professor E. H. Williams, University of Puerto Rico, for additional comments and suggestions on the text

\section{LITERATURE CITED}

Anderson DM, Lobel PS (1987) The continuing enigma of ciguatera. Biol Bull 172:89-107

Atwood DK (ed) (1981) Unusual mass fish mortalities in the Caribbean and Gulf of Mexico. Atlantic Oceanographic and Meteorological Laboratories, Mlami, Florida, USA

Bagnis $R$, Legrand A-M, Inoue A (1990) Follow-up of a bloom of the toxic dinoflagellate Gambierdiscus toxicus on a fringing reef of Tahiti. In: Graneli E, Sundstrom B, Edler L, Anderson DM (eds) Toxic marine phytoplankton. Elsevier Press, Amsterdam, p 98-103

Balazs GH. (1982) Growth rates of immature green turtles in the Hawaiian archipelago. In: Bjorndal KA (ed) Biology and conservation of sea turtles. Proceedings of World Conference of Sea Turtle Conservation. Smithsonian Institution Press, Washington DC, p 117-125

Banner AP, Helfrich P, Piyakarnchana T (1966) Retention of ciguatera toxin by the red snapper, Lutjanus bohar Copeia 1966:297-301

Basson L, Van As JG. Fishelson L (1990) A new species of Trichodina (Ciliophora:Peritrichia) from the intestine of the surgeonfish Acanthurus xanthopterus. Int J Parasitol 20:785-787

Bomber JW, Morton SL, Babinchak JA, Norris DR, Morton JG (1988) Epiphytic dinoflagellates of drift algae - another toxigenic community in the ciguatera food chain. Bull mar Sci 43:204-214

Bomber JW, Rubio MG, Norris DR (1989) Epiphytism of dinoflagellates associated with the disease ciguatera: substrate specificity and nutrition. Phycologia 28:360-368

Burns CD (1981) A report on the 1980 fish kill along the Florida reef track. In: Atwood DK (ed) Unusual mass fish mortalities in the Caribbean and Gulf of Mexico. Atlantic Oceanographic and Meteorological Laboratories, Miami, Florida, $p$ 36-41

Cannon LRG, Lester RJG (1988) Two turbellarians parasitic in fish. Dis aquat Org 5:15-22

Capra MF, Cameron J, Flowers AE, Coombe IF, Blanton CG, Hahn ST (1988) The effects of ciguatoxin on teleosts. In: Hutchings P (ed) Proc 6th int Coral Reef Congr, p $37-41$
Carlson PR, Barber TR (1994) 'Blooms' of the macroalga Codium isthmocladum on South Florida reefs. American Society of Limnology and Oceanography/Phycology Soclety, American Conference, University of Miami, Florida, p A-13

Cheung PJ, Nigrelli RF, Ruggieri GD (1980) Studies on the morphology of Uronema marinum Dujardin (Ciliatea: Uronematidae) with a description of the histopathology of the infection in marine fishes. J Fish Dis 3:295-303

Chevaldonné P (1990) Ciguatera and the saupe, Sarpa salpa (L.), in the Mediterranean: a possible misinterpretation. J Fish Biol 37:503-504

Clements KD, Sutton DC, Choat JH (1989) Occurrence and characteristics of unusual protistan symbionts from surgeon fishes (Acanthuridae) of the Great Barrier Reef, Australia. Mar Biol 102:403-412

Coles SL (1994) Extensive coral disease outbreak at Fahl Island, Gulf of Oman, Indian Ocean. Coral Reefs 13:242

Coulson JC, Potts GR, Deans IR, Fraser SM (1968) Exceptional mortality of shags and other seabirds caused by paralytic shellfish poison. Brit Birds 61:381-404

Davin WT Jr, Kohler CC, Tindall DR (1986) Effects of ciguatera toxins on the bluehead. Trans Am Fish Soc 115:908-912

Davin WT Jr, Kohler CC, Tindall DR (1988) Ciguatera toxins adversely affect piscivorous fishes. Trans Am Fish Soc 117: $374-384$

Endean R (1977) Destruction and recovery of coral reef communities. In: Jones OA, Endean R (eds) Biology and geology of coral reefs. Academic Press, New York, p 215-254

Endean R, Monks SA, Griffith JK, Llewellyn LE (1993) Apparent relationships between toxins elaborated by the cyanobacterium Trichodesmium erythraeum and those present in the flesh of the narrow-barred Spanish mackerel Scomberomorus commersoni. Toxicon 31:1155-1165

Gavagnin M, Marin A, Castelluccio F, Villani G, Cimino G (1994) Defensive relationships between Caulerpa prolifera and its shelled sacoglossan predators. J exp mar Biol Ecol 175:197-210

Geraci JR, Anderson DM, Timperi RJ, Staubin DJ, Early GA, Prescott JH, Mayo CA (1989) Humpback whales (Megaptera novaeangliae) fatally poisoned by dinoflagellate toxin. Can J Fish aquat Sci 46:1895-1898

Gonzalez G, Brusle J, Crespo S (1994) Ultrastructural alterations of cabrilla sea bass Serranus cabrilla liver related to experimental Gambierdiscus toxicus (dinoflagellate) ingestion. Dis aquat Org 18:187-193

Gorlick DL, Atkins PD, Losey GS (1987) Effect of cleaning by Labroides dimidiatus (Labridae) on an ectoparasite population infecting Pomacentrus vaiuli (Pomacentridae) at Enewetak Atoll. Copeia 1987:41-45

Grim JN (1988) A somatic kinetid study of the pycnotrichid ciliate Vestibulongum corlissi n.g., n.sp. (Class: Listostomata), symbiont in the intestine of the surgeonfish Acanthurus xanthopterus. J Protozool 35:227-230

Grizzle JM, Williams EH Jr (1985) Lesions of a rock beauty, Holacanthus tricolor (Bloch), from Puerto Rico. J Fish Dis 8:129-134

Guo C. Tester PA (1994) Toxic effect of the bloom-forming Trichodesmium sp. (Cyanophytal to the copepod Acartia tonsa. Nat Toxins 2:222-227

Hahn ST, Capra MF (1992) The cyanobacterium Oscillatoria erythraed - a potential source of toxin in the ciguatera food chain. Food Addit Contam 9:351-355

Holmes MJ, Lewis RJ, Poli MA, Gillespie NC (1991) Strain dependent production of ciguatoxin precursors (gambiertoxins) by Gambierdiscus toxicus) (Dinophyceae) in culture. Toxicon 29:761-775 
Hourigan TF, Stanton FG, Motta PJ, Kelley CD, Carlson B (1989) The feeding ecology of three species of angelfishes (family Pomacanthidae). Environ Biol Fish 24:105-116

Hughes TP (1994) Catastrophes, phase shifts, and large-scale degradation of a Caribbean coral reef. Science 265: $1547-1551$

Jaap W (1988) The 1987 zooxanthellae expulsion event at Florida reefs. In: Ogden JC, Wicklund Rl (eds) Mass bleaching of coral reefs in the Caribbean: a research strategy. NOAA Research Report, 88-2, p 24-29

Jones GM (1985) Paramoeba invadens n. sp. (Amoebida Paramoebidae), a pathogenic amoeba from the sea urchin Strongylocentrotus droebachiensis in eastern Canada. J Protozool 32:564-569

Kelly AM, Kohler CC, Tindall DR (1992) Are crustaceans linked to the ciguatera food chain? Environ Biol Fish 33 . $275-286$

Kent ML, Olson AC Jr (1986) Interrelationships of a parasitic turbellarian (Paravortex sp.) (Graffillidae, Rhabdocoela) and its marine fish hosts. Fish Pathol 21:65-72

Kent ML, Sawyer TK, Hedrick RP (1988) Paramoeba pemaquidiensis (Sarcomastigophora: Paramoebidae) infestation of the gills of coho salmon Oncorhynchus kisutch reared in sea water. Dis aquat Org 5:163-169

Kohler ST, Kohler CC (1992) Dead bleached coral provides new surfaces for dinoflagellates implicated in ciguatera fish poisonings. Environ Biol Fish 35:413-416

Kohler CC, Paleudis GA, Tindall DR (1989) Behavior abnormalities displayed by ocean surgeon following consumption of ciguatoxigenic dinoflagellates. Proc Ass Island mar Labs Caribb 22:34

Landsberg JH, Blakesley BA (1995) A scanning electron microscope study of Brooklynella hostilis (Protista, Ciliophora) isolated from the gills of gray and French angelfish in Florida. J aquat Anim Health 7:58-62

Lapointe BE (1989) Caribbean coral reefs: are they becoming algal reefs? Sea Frontiers 35:82-91

Legrand A-M, Fukui M, Cruchet P, Ishibashi Y, Yasumoto T (1992) Characterization of ciguatoxins from different fish species and wild Gambierdiscus toxicus. In: Tosteson TR (ed) Proceedings of the Third International Conference on Ciguatera Fish Poisoning. Polyscience Publications Quebec, p 25-32

Lewis SJ (1992) Ciguatoxins are potent ichthyotoxins Toxicon 30:207-211

Littler MM, Taylor PR, Littler DS (1983) Algal resistance to herbivory on a Caribbean barrier reef. Coral Reefs 2 $111-118$

Lobel J, Ogden JC (1981) Foraging by the herbivorous parrotfish, Sparisoma radians. Mar Biol 64:173-183

Lom J, Dyková I (1992) Protozoan parasites of fishes. Elsevier Science Publishers, Amsterdam

Lom J, Nigrelli RF (1970) Brooklynella hostilis n. g., n. sp., a pathogenic cyrtophorine ciliate in marine fishes. J Protozool 17:224-232

Love M, Tebeken-Fisher D, Hose JE, Farmer JJ III, Hickman FW, Fanning GR (1981) Vibrio damsela, a marine bacterium, causes skin ulcers on the damselfish Chromis punctipinnis. Science 214:1139-1140

Magnelia SJ, Kohler CC, Tindall DR (1992) Acanthurids do not avoid consuming cultured toxic dinoflagellates yet do not become ciguatoxic. Trans Am Fish Soc 121: $737-745$

Meyer KD, Paul VJ (1992) Intraplant variation in secondary metabolite concentration in three species of Caulerpa (Chlorophyta: Caulerpales) and its effects on herbivorous fishes. Mar Ecol Prog Ser 82:249-257
Neudecker S (1985) Foraging patterns of chaetodontid and pomacanthid fishes at St. Croix. In: Gabrie C. Salvat B (eds) Proc 5th int Coral Reef Congr, p 415-420

Ogden JC, Lobel PS (1978) The role of herbivorous fishes and urchins in coral reef communities. Environ Biol Fish 3: $49-63$

Pastorok RA, Bilyard GR (1985) Effects of sewage pollution on coral-reef communities. Mar Ecol Prog Ser 21:175-189

Paul VJ (1987) Feeding deterrent effects of algal natural products. Bull mar Sci 41:514-522

Paul VJ, Fenical W (1986) Chemical defense in tropical green algae, order Caulerpales. Mar Ecol Prog Ser 34:157-169

Quintero-Hunter 1, Grier H, Muscato M (1991) Enhancement of histological detail using metanil yellow as a counterstain in periodic acid/Schiff's hematoxylin staining of glycol methacrylate tissue sections. Biotech Histochem 66: $169-172$

Randall JE (1958) A review of ciguatera, tropical fish poisoning, with a tentative explanation of its cause. Bull mar Sci $8: 236-267$

Randall JE, Hartman WD (1968) Sponge-feeding fishes of the West Indies. Mar Biol 1:216-225

Robblee MB, Barber TR, Carlson PR Jr, Durako MJ, Fourqurean JW, Muehlstein LK, Porter D, Yarbro LA, Zieman RT, Zieman JC (1991) Mass mortality of the tropical seagrass Thalassia testudinum in Florida Bay (USA). Mar Ecol Prog Ser 71:297-299

Sawyer TK (1980) Marine amebae from clean and stressed bottom sediments of the Atlantic Ocean and Gulf of Mexico. J Protozool 27:13-32

Spanier E, Finkelstein Y, Raikhlin-Eisenkraft B (1989) Toxicity of the saupe, Sarpa salpa (Linnaeus, 1758), on the Mediterranean coast of Israel. J Fish Biol 34:635-636

Sutton DC, Clements KD (1988) Aerobic, heterotrophic gastrointestinal microflora of tropical marine fishes. In: Hutchings $P$ (ed) Proc 6th int Society of Reef Studies. p $185-190$

Swift AEB, Swift TR (1993) Ciguatera. Clin Toxicol 31:1-29

Targett NM, Mitsui A (1979) Toxicity of subtropical marine algae using fish mortality and red blood cells hemolysis for bioassays. J Phycol 15:181-185

Toranzo AE, Novoa B, Romalde JL, Nuñez $S$, Devesa $S$, Mariño E, Silva R, Martínez E, Figueras A, Barja JL (1993) Microflora associated with healthy and diseased turbot (Scophthalmus maximus) from three farms in northwest Spain. Aquaculture 114:189-202

Vidal JP, Laurent D, Kabore SA, Rechencq E, Boucard M, Girard JP, Escale R, Rossi JC (1984) Caulerpin, caulerpicin, Caulerpa scalpelliformis: comparative acute toxicity study. Bot mar 27:533-537

White AW (1981a) Recurrence of kills of Atlantic herring (Clupea harengus harengus) caused by dinoflagellate toxins transferred through herbivorous zooplankton. Can J Fish Aquat Sci 37:2262-2265

White AW (1981b) Marine zooplankton can accumulate and retain dinoflagellate toxins and cause fish kills. Limnol Oceanogr 26:103-109

White AW (1981c) Sensitivity of marine fishes to toxins from the red-tide dinoflagellate Gonyaulax excavata and implications for fish kills. Mar Biol 65:255-260

White AW, Fukuhara O, Anraku M (1989) Mortality of fish larvae from eating toxic dinoflagellates or zooplankton containing dinoflagellates. In: Okaichi $T$, Anderson DM, Nemoto $T$ (eds) Red tides, biology, environmental science and toxicology. Elsevier Press, New York, p 395-398

Williams EH Jr, Bunkley-Williams L (1987) Caribbean mass mortalities: a problem with a solution. Oceanus $30: 69-75$ 
Williams EH Jr, Bunkley-Williams L (1990a) Recurring mass mortalities of Caribbean herrings: implications for the study of major marine ecological disturbances. J aquat Anim Health 2:230--236

Williams EH Jr, Bunkley-Williams L (1990b) The world-wide coral reef bleaching cycle and related sources of coral mortality. Atoll Res Bull 335:1-71

Williams EH Jr, Bunkley-Williams $L$, Peters EC, PintoRodriguez $B$, Matos-Morales R, Mignucci-Giannoni AA, Hall KV, Rueda-Almonacid JV, Sybesma J, Bonnelly de

Responsible Subject Editor: W. Körting, Hannover, Germany
Calventi I, Boulon RH (1994) An epizootic of cutaneous fibropapillomas in green turtles Chelonia mydas of the Caribbean: part of a panzootic? $J$ aquat Anim Health 6:70-78

Work TM, Beale AM, Fritz L, Quilliam MA, Silver M, Buck K, Wright JLC (1993) Domoic acid intoxication of brown pelicans and cormorants in Santa Cruz, California. In: Smayda TJ, Shimuzu Y (eds) Toxic phytoplankton in the sea. Elsevier Science Publishers, Amsterdam, p 643-649

Manuscript first received: November 20,1994 Revised version accepted: February 14, 1995 